\title{
Antithyroid antibodies - a possible involvement in the development of chronic periodontitis
}

\author{
Anticorpii antitiroidieni - o posibilă implicare în \\ dezvoltarea parodontitei cronice
}

\author{
Razvan Circo', Marian Beciu², Cristina Circo', Doina Raducan², Victoria Badea ${ }^{3}$ \\ ${ }^{1}$ Circo Dentistry, Bucureşti, România \\ 2Disciplina Endocrinologie, Facultatea de Medicină, Universitatea „Ovidius“, Constanţa, România \\ ${ }^{31}$ munologie, Facultatea de Medicină Dentară, Universitatea „Ovidius“, Constanţa, România
}

\begin{abstract}
Objectives. Identification of periodontal lesions in patients with chronic autoimmune thyroiditis (CAT) assessed differently depending on their severity and the average serum level of thyroid autoantibodies.

Material and methods. The study was initiated in a group of patients $(n=133)$ diagnosed with chronic autoimmune thyroiditis in conditions of normal thyroid function and without other comorbidities. Examination of the oral cavity identified lesions characteristic of chronic periodontitis (CP) classified according to their intensity in - mild, medium and aggravated in a group of 109 patients. The serum level of thyroid autoantibodies - as a mean value - was analyzed in a group of 77 patients with similar periodontal lesions related to their classification.

Results. Characteristic ethological changes of chronic periodontitis were identified in $85 \%$ of patients being classified as: mild $(40.2 \%)$, medium $(31.9 \%)$, aggravated $(28.5 \%)$. Thyroid autoantibodies were present: $62.3 \%$ for antithyroperoxidase antibodies (ATPO), $23.8 \%$ for both ATPO and antithyroglobulin antibodies (ATG); $13.7 \%$ for ATG. The differentiated statistical calculation of the average values of antibodies found for ATPO presented a high statistical significance $(p<0.0002)$ for spontaneous bleeding, all degrees of tooth mobility, depth of periodontal pockets, root fork and dental occlusion. No statistical significance was found for ATPO in bacterial plaque and gingival regression. No statistical significance was recorded for the mean level of ATG.

Conclusions. The correlation of the serum level of thyroid autoantibodies with the specificity of periodontal lesions certify a possible differentiated involvement of them. For ATPO, extra-thyroid systemic effects can be suggested as a priority.
\end{abstract}

Keywords: chronic periodontitis, chronic autoimmune thyroiditis, antithyroid autoantibodies

\section{REZUMAT}

Obiective. Identificarea leziunilor parodontale la pacienți cu tiroidită cronică autoimună apreciate diferențiat în funcție de gravitatea lor și de nivelul seric mediu al autoanticorpilor tiroidieni.

Material şi metode. Studiul a fost inițiat pe un lot de pacienți $(n=133)$ diagnosticați cu tiroidită cronică autoimună în condiții de normofuncție tiroidiană și fără alte comorbidităţi. Examenul cavității orale a identificat leziuni caracteristice parodontitei cronice, clasificate, după intensitatea lor, în incipiente, medii, agravate la 109 pacienți. Nivelul seric al autoanticorpilor tiroidieni - ca valoare medie - a fost analizat la 77 pacienți cu leziuni similare parodontale corelate clasificării lor.

Rezultate. Modificările patologice caracteristice parodontitei cronice au fost identificate la $85 \%$ dintre pacienți, fiind clasificate în: incipiente $(40,2 \%)$, de intensitate medie $(31,9 \%)$, agravate $(28,5 \%)$. Prezenţa autoanticorpilor tiroidieni a fost: $62,3 \%$-ATPO și AcTg; 23,8\% ATPO; 13,7\%-AcTg. Calculul statistic diferențiat al valorilor medii ale anticorpilor a constatat pentru ATPO o semnificație statistică înaltă $(p<0,0002)$ pentru sângerarea spontană, toate gradele de mobilitate dentară, profunzimea pungilor parodontale, a furcaţiei radiculare și pentru ocluzia dentară modificată. Nu s-a constatat o semnificație statistică pentru ATPO în cazul plăcii bacteriene și al regresiei gingivale. Pentru nivelul mediu al AcTg nu s-a înregistrat nicio semnificație statistică. Concluzii. Corelarea nivelului seric al autoanticorpilor tiroidieni cu specificul leziunilor parodontale atestă o posibilă implicare diferențiată a acestora. Pentru ATPO, se pot sugera prioritar efecte sistemice extratiroidiene.

Cuvinte cheie: parodontită cronică, tiroidită cronică autoimună, autoanticorpi antitiroidieni 


\author{
Abrevieri \\ $\mathrm{PC}$ - parodontită cronică; \\ TCA - tiroidită cronică autoimună; \\ Ac - anticorpi; \\ ATPO - anticorpi antitiroperoxidază; \\ AcTg - anticorpi antitiroglobulină
}

\section{INTRODUCERE}

Parodontita este o boală inflamatorie asociind procese distructive la nivelul unor componente ale cavității orale prin mecanisme de natură autoimună supraexprimate (1). Gingivita precede amorsarea proceselor distructive și, în 10-15\% dintre cazuri, prin cronicizare, va produce degradarea colagenului (2). Sub influența factorilor aleatori de mediu $(3,4)$, care vor acționa asupra variabilității individuale genice (5), poate evolua spre boala parodontală pe substrat autoimun, inițiat de disbioza microbiomului cavității orale $(6,7)$. Alterarea adaptativă a celulelor cu rol imunitar - limfocite $\mathrm{T}$ în gingivita și, respectiv, limfocite B în parodontita cronică -, în strânsă corelație patogenică cu agresiunea florei microbiene orale (8), va avea drept consecințe distrucţia țesutului conectiv și intensificarea resorbției osoase alveolare, stimulând osteoprotegerina (RANK-L), ligandul activator al sistemului RANK, și factori reglatori ai metabolismului osos: IL-6 și IL-8 (9). Leziunile parodontale sunt întâlnite frecvent la pacienții cu tiroidită cronică autoimună (10), fiind posibilă o implicare a disfuncției tiroidiene și a autoimunității caracteristic distructivă la nivel tisular tiroidian (11). Deși tulburările funcționale tiroidiene sunt implicate direct în realizarea leziunilor parodontale la nivelul țesutului conjunctiv (2) și osos (9), precum şi indirect, prin stimularea agresiunii microbiomului în condiții de igienă orală deficitară (12) sau modificarea compoziției microbiene salivare cu asocierea insulinorezistenţei (13), prezența unor modificări de tip oxidativ la nivel salivar în cazul unor pacienți cu tiroidită cronică autoimună evoluând în condiții de normotiroidie atestă un posibil rol şi al altor factori în geneza leziunilor parodontale (14). Asocierea parodontitei și a tiroiditei autoimune cu alte boli cronice este frecventă, fiind realizată prin mecanism inflamator și autoimun (15). Evaluarea unui posibil rol al autoanticorpilor tiroidieni în realizarea și progresia bolii parodontale la pacienții cu TCA ar putea deschide perspective terapeutice utile ambelor categorii de bolnavi.

\section{OBIECTIVE}

Evidențierea prezenței leziunilor parodontale la pacienții cu tiroidită cronică autoimună și corela- rea acestora cu specificul și particularitățile distribuției autoanticorpilor antitiroidieni.

\section{MATERIAL ŞI METODE}

Lotul de studiu a cuprins 133 pacienți noudiagnosticați cu tiroidită cronică autoimună prin examen clinic, examen ecografic tiroidian și dozajul nivelului seric (ECHEM) al autoanticorpilor tiroidieni: ATPO (valori patologice $>35 \mathrm{UI} / \mathrm{ml}$ ), $\operatorname{AcTg}(>115 \mathrm{UI} / \mathrm{ml})$ și al hormonilor tiroidieni FT4 (12-22 pmol/1); FT3 (3,1-6,8 pmol/1), TSH $(0,27-4,2 \mathrm{mUI} / \mathrm{ml})$.

\section{Caracteristicile lotului}

16 persoane de sex masculin (12,03\%) și 117 persoane de sex feminin (87.97\%); media de vârstă $-38,6 \pm 11,5$ ani.

\section{Criteriile de selecționare a pacienților}

Criterii de includere: nivel seric hormonal tiroidian normal, cazuri nou diagnosticate, fără tratament substitutiv cu tiroxină.

Criterii de excludere: alte boli autoimune, boli inflamatorii, neoplazice, diabet zaharat, parodontită agresivă, fumători, femei gravide sau la menopauză, igienă orală defectuoasă.

\section{Criteriile de evaluare a leziunilor parodontale}

Pacienții au fost examinați din punctul de vedere al statusului dentar, identificându-se leziuni caracteristice parodontitei cronice în acord cu clasificarea acestora conform recomandărilor Federaţiei Europene de Parodontologie, în acord cu conceptul aprecierii dinamice a evoluției stadiale a parodontitei cronice (16).

\section{Analiza statistică}

Pentru modificările constatate prin examen clinic, am utilizat testul $\mathrm{T}$ pentru variabile continue apreciate comparativ. Semnificaţia statistică a fost determinată la o valoare $\mathrm{p}<0,001$, iar $\mathrm{p}<0,05 \mathrm{~s}-\mathrm{a}$ considerat o posibilă corelaţie statistică. O serie de valori au fost exprimate procentual (\%) şi/sau ca valoare medie \pm deviaţia standard (DS). Pentru interpretarea rezultatelor obţinute, având în vedere aprecierea gravitații și amplorii leziunilor parodontale, au fost folosite: testul Chi pătrat pentru parametri nonnumerici, fiind analizată distribuţia 
frecvenţelor; testul t Student; regresia liniară simplă şi multifactorială (coeficientul r Pearson); testul ANOVA pentru compararea rezultatelor din cele două loturi.

\section{REZULTATE}

Modificări patologice constatate prin examenul de specialitate al cavității orale a pacienților cu TCA au fost identificate la 109 pacienți $(85 \%)$, dintre care 5 pacienți de sex masculin $(4,5 \%)$ și 104 pacienți de sex feminin $(95,5 \%)$.

Distribuția leziunilor parodontale, intricate adesea la același pacient, a avut următoarele valori procentuale ale tipului lezional constatate în rândul celor 109 pacienți prezentând PC asociată TCA (Tabel 1).

TABEL 1. Incidență tipuri şi distribuție leziuni parodontale - pacienți cu tiroidită cronică autoimună

\begin{tabular}{|c|c|c|}
\hline Leziuni parodontale & $\begin{array}{c}\text { Pacienți cu } \\
\text { PC } \\
\text { (N = 109) }\end{array}$ & $\%$ \\
\hline 1. Placă bacteriană/depozit tartru & 109 & 100 \\
\hline \multicolumn{3}{|l|}{ 2. Sângerare } \\
\hline Spontană & 51 & 38,35 \\
\hline La sondare & 82 & 61,65 \\
\hline 3. Recesia marginii gingivale & 103 & 77,44 \\
\hline \multicolumn{3}{|l|}{ 4. Mobilitate dentară } \\
\hline Grad 1 & 90 & 67,67 \\
\hline Grad 2 & 37 & 27,82 \\
\hline Grad 3 & 6 & 4,51 \\
\hline \multicolumn{3}{|c|}{ 5. Profunzime pungi parodontale - sondare } \\
\hline \begin{tabular}{l|l|} 
& Ușoară 1-2 mm \\
\end{tabular} & 44 & 33,08 \\
\hline Medie 3-4 mm & 74 & 55,64 \\
\hline Gravă > 5 mm & 15 & 11,28 \\
\hline \multicolumn{3}{|l|}{ 6. Furcație radiculară } \\
\hline Grad $1<3 \mathrm{~mm}$ & 77 & 57,89 \\
\hline Grad $2>3 \mathrm{~mm}$ & 44 & 33,08 \\
\hline Grad 3 penetrare completă & 12 & 9,02 \\
\hline 7. Ocluzia dentară modificată & 25 & 18,8 \\
\hline
\end{tabular}

Pacienții cu TCA și leziuni parodontale au fost clasificați după specificul expresiei autoanticorpilor tiroidieni ca incidență și nivel seric mediu (Tabel 2).

TABEL 2. Anticorpi antitiroidieni - caracteristici de distributie $(n=109)$

\begin{tabular}{|l|c|c|c|}
\hline & ATPO & AcTg & ATPO + AcTg \\
\hline Nr. pacienți & 26 & 15 & 68 \\
\hline $\begin{array}{l}\text { Valoare procentuală } \\
\text { (\%) }\end{array}$ & 23,8 & 13,7 & 62,3 \\
\hline $\begin{array}{l}\text { Valoare medie nivel } \\
\text { seric autoanticorpi } \\
\text { (Ul/ml) }\end{array}$ & $232 \pm 206$ & $353 \pm 271$ & $343 \pm 125 /$ \\
$412 \pm 108$ \\
\hline
\end{tabular}

Conform metodologiei de apreciere a intensității și întinderii leziunilor parodontale, 77 de pacienți cu TCA și PC au fost clasificați în funcție de complicațiile bolii parodontale, apreciindu-se, totodată, specificul expresiei autoimunității tiroidiene în cadrul fiecărui grup de pacienți studiat în mod diferentiat ca valori medii ale nivelului seric ATPO și, respectiv, AcTg pentru identificarea unor implicaţii diferite ale autoanticorpilor (Tabel 3).

TABEL 3. Tipul leziunilor parodontale, corelat cu nivelul seric mediu al autoanticorpilor tiroidieni

\begin{tabular}{|l|c|c|c|}
\hline $\begin{array}{l}\text { PC - tip lezional } \\
n=77\end{array}$ & $\begin{array}{c}\text { ATPO } \\
(\mathbf{n}=\mathbf{2 8})\end{array}$ & $\begin{array}{c}\text { AcTg } \\
(\mathrm{n}=23)\end{array}$ & $\begin{array}{c}\text { ATPO /AcTg } \\
(\mathbf{n}=\mathbf{2 6})\end{array}$ \\
\hline $\begin{array}{l}\text { PC- incipientă } \\
\mathrm{n}=31(40,2 \%)\end{array}$ & $\begin{array}{c}\mathrm{n}=13 \\
(16,8 \%)\end{array}$ & $\begin{array}{c}\mathrm{n}=8 \\
(10,3 \%)\end{array}$ & $\begin{array}{c}\mathrm{n}=10 \\
(13 \%)\end{array}$ \\
\hline $\begin{array}{l}\text { Valoare medie } \\
\text { autoanticorpi }\end{array}$ & $218 \pm 78$ & $306 \pm 18$ & $204 \pm 24$ \\
\hline PC- intensitate & $\mathrm{n}=7$ & $\mathrm{n}=12$ & $\mathrm{n}=5$ \\
medie & $(9 \%)$ & $(15,5 \%)$ & $(6,5 \%)$ \\
$\mathrm{n}=24(31,9 \%)$ & & & \\
\hline $\begin{array}{l}\text { Valoare medie } \\
\text { autoanticorpi }\end{array}$ & $224 \pm 111$ & $236 \pm 14$ & $482 \pm 84$ \\
\hline PC-agravată & $\mathrm{n}=8$ & $\mathrm{n}=3$ & $\mathrm{n}=11$ \\
$\mathrm{n}=22$ (28,5\%) & $(10,3 \%)$ & $(3,8 \%)$ & $(14,2 \%)$ \\
\hline Valoare medie & $292 \pm 114$ & $402 \pm 12$ & $395 \pm 62 /$ \\
anticorpi & & & $496 \pm 98$ \\
\hline
\end{tabular}

Există diferenţă statistică între valorile medii ale concentraţiei serice ale ATPO în funcţie de tipul leziunilor parodontale $(\mathrm{p}=0,00002)$, de asemenea, există diferenţă statistică şi între valorile medii ATPO comparate între grupul pacienţilor cu leziuni agravate şi cei cu leziuni medii $(p=0,000232)$, precum şi între cei cu leziuni agravate şi leziuni incipiente ( $p=0,000003)$. Nu se remarcă o diferenţă statististică semnificativă între valorile ATG şi tipul leziunilor parodontale ( $\mathrm{p}=$ 0,06138) (Fig. 1).

\section{Prezența plăcii bacteriene, corelată cu nivelul mediu al Ac antitiroidieni}

Nu există diferență statistică semnificativă între valorile medii ale concentraţiei serice ale ATPO în funcţie de prezenţa plăcii bacteriene $(p=0,10040)$, de asemenea, nu există diferenţă statistică între valorile ATG şi prezenţa plăcii bacteriene (p = 0,17681) (Tabel 4).

TABEL 4. Placa bacteriană

\begin{tabular}{|l|c|c|}
\hline \multicolumn{1}{|c|}{ Placa bacteriană } & ATPO medie & ATG medie \\
\hline Prezentă & $468 \pm 242$ & $245 \pm 112$ \\
\hline Absentă & $365 \pm 124$ & $175 \pm 84$ \\
\hline$P$ & 0,10040 & 0,17681 \\
\hline
\end{tabular}




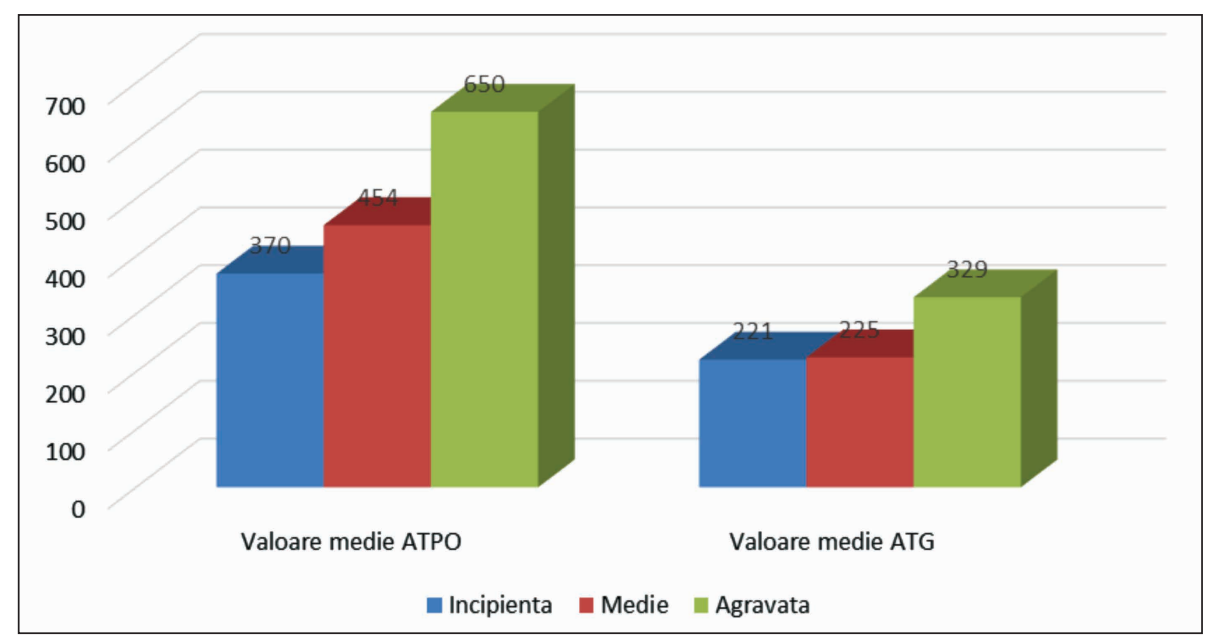

FIGURA 1. Tipul leziunilor parodontale corelat cu nivelul seric mediu al anticorpilor

\section{Prezența sângerării gingivale, corelată cu nivelul mediu al Ac antitiroidieni}

Diferenţa statistică este prezentă între valorile medii ale concentraţiei serice ale ATPO în funcţie de prezenţa sângerării spontane gingivale $(\mathrm{p}=$ 0,00045) comparativ cu sângerarea la sondare, de asemenea, nu există diferenţă statistică între valorile ATG şi prezenţa sângerării gingivale $(\mathrm{p}=$ 0,13016) (Tabel 5).

TABEL 5. Sângerare gingivală

\begin{tabular}{|l|c|c|}
\hline Sângerare gingivală & ATPO medie & ATG medie \\
\hline La sondare & $407 \pm 198$ & $220 \pm 94$ \\
\hline Spontană & $539 \pm 214$ & $267 \pm 115$ \\
\hline P & 0,000447 & 0,13016 \\
\hline
\end{tabular}

Prezenţa recesiei gingivale, corelată cu nivelul mediu al Ac antitiroidieni

Diferenţa statistică este prezentă între valorile medii ale concentraţiei serice ale ATPO în funcţie de existenţa recesiei gingivale $(p=0,00571)$ comparativ cu un prag de 0,05 ; de asemenea, nu există diferenţă statistică între valorile ATG şi prezenţa recesiei gingivale dentare $(\mathrm{p}=0,41309)$ (Tabel 6).

TABEL 6. Recesia gingivală

\begin{tabular}{|l|c|c|}
\hline Recesia gingivală & ATPO medie & ATG medie \\
\hline Prezentă & $485 \pm 214$ & $245 \pm 175$ \\
\hline Absentă & $363 \pm 172$ & $215 \pm 162$ \\
\hline$P$ & 0.00571 & 0.41309 \\
\hline
\end{tabular}

\section{Gradul mobilităţii dentare, corelat cu nivelul mediu al Ac antitiroidieni}

Există diferenţă statistică între valorile medii ale concentraţiei serice ale ATPO în funcţie de gradul mobilităţii dentare ( $<<0,00001)$, de asemenea, există diferenţă statistică şi între valorile medii ATPO comparate între grupul pacienţilor cu mobilitate de grad 3 faţă de cei de grad $1(p=0,000123)$, precum şi între cei cu grad 2 faţă de cei cu grad 1

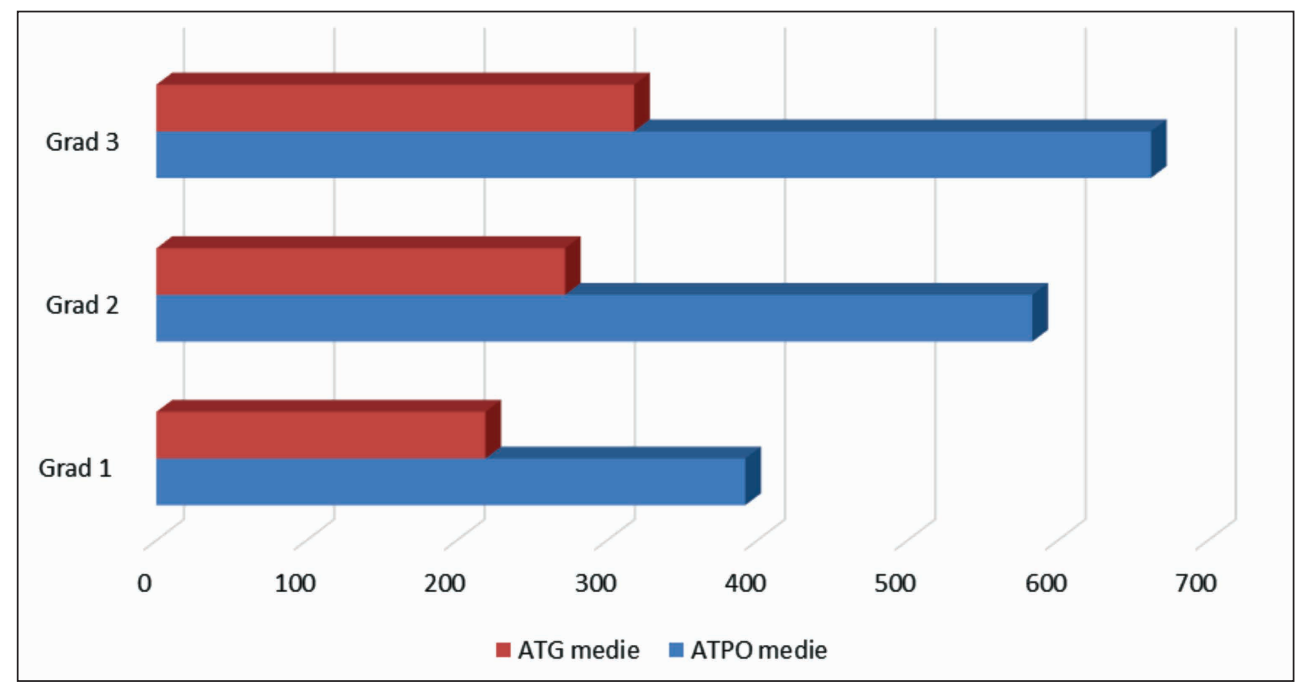

FIGURA 2. Gradul mobilității dentare, corelat cu nivelul mediu al Ac antitiroidieni 
$(p=0,000002)$. Nu se remarcă o diferenţă statististică semnificativă între valorile ATG şi gradul mobilităţii dentare $(p=0,15835)$ (Tabel 7, Fig. 2).

TABEL 7. Mobilitatea dentară

\begin{tabular}{|l|c|c|}
\hline Mobilitate dentară & ATPO medie & ATG medie \\
\hline Grad 1 & $392 \pm 181$ & $219 \pm 111$ \\
\hline Grad 2 & $583 \pm 236$ & $272 \pm 123$ \\
\hline Grad 3 & $662 \pm 375$ & $318 \pm 194$ \\
\hline P & $<0,00001$ & 0,15835 \\
\hline
\end{tabular}

\section{Profunzimea pungii parodontale, corelată cu} nivelul mediu al Ac antitiroidieni

Exista diferenţă statistică între valorile medii ale concentraţiei serice ale ATPO în funcţie de profunzimea pungii parodontale $(\mathrm{p}=0,00001)$, de asemenea, există diferenţa statistică şi între valorile medii ATPO comparate între grupul pacienţilor cu leziune gravă faţă de cei cu leziune uşoară $(p=$ 0,000002 ), precum şi între cei cu leziune medie faţă de cei cu leziune uşoară $(p=0,000808)$. Nu se remarcă o diferenţă statististică semnificativă între valorile ATG şi profunzimea pungii parodontale ( $\mathrm{p}$ $=0,07408)($ Tabelul 8, Fig. 3).

TABEL 8. Profunzimea pungii parodontale

\begin{tabular}{|l|c|c|}
\hline $\begin{array}{l}\text { Profunzimea pungii } \\
\text { parodontale }\end{array}$ & ATPO medie & ATG medie \\
\hline Gravă & $662 \pm 224$ & $320 \pm 111$ \\
\hline Medie & $470 \pm 186$ & $243 \pm 105$ \\
\hline Ușoară & $367 \pm 200$ & $202 \pm 94$ \\
\hline$p$ & 0,00001 & 0,07408 \\
\hline
\end{tabular}

\section{Gradul furcaţiei radiculare corelat cu nivelul mediu al Ac antitiroidieni}

Există diferență statistică între valorile medii ale concentraţiei serice ale ATPO în funcţie de gra- dul furcaţiei radiculare $(p=0,00002)$, de asemenea, există diferenţă statistică şi între valorile medii ATPO comparate între grupul pacienţilor cu furcație de $\operatorname{grad} 3$ față de cei de $\operatorname{grad} 1$ ( $p=$ $0,000011)$, precum şi între cei cu grad 2 faţă de cei cu grad $1(p=0,007815)$. Nu se remarcă o diferenţă statististică semnificativă între valorile ATG şi gradul furcaţiei radiculare $(\mathrm{p}=0,25110)$ (Tabel 9, Fig. 4).

TABEL 9. Furcația radiculară

\begin{tabular}{|l|c|c|}
\hline Furcație radiculară & ATPO medie & ATG medie \\
\hline Grad 1 & $399 \pm 192$ & $217 \pm 170$ \\
\hline Grad 2 & $500 \pm 216$ & $267 \pm 183$ \\
\hline Grad 3 & $621 \pm 249$ & $273 \pm 178$ \\
\hline$p$ & 0,00002 & 0,25110 \\
\hline
\end{tabular}

\section{Prezenţa ocluziei dentare modificate, corelată cu nivelul mediu al Ac antitiroidieni}

Diferenţa statistică este prezentă între valorile medii ale concentraţiei serice ale ATPO în funcţie de existenţa modificărilor ocluziei dentare $(\mathrm{p}=$ 0,01 ) comparativ cu un prag de 0,05 ; de asemenea, nu există diferenţă statistică între valorile ATG şi prezenţa modificărilor ocluziei dentare $(\mathrm{p}=$ 0,32335) (Tabel 10).

TABEL 10. Ocluzia dentară modificată

\begin{tabular}{|l|c|c|}
\hline $\begin{array}{l}\text { Ocluzie dentară } \\
\text { modificată }\end{array}$ & ATPO medie & ATG medie \\
\hline Prezentă & $556 \pm 184$ & $270 \pm 118$ \\
\hline Absentă & $435 \pm 206$ & $331 \pm 201$ \\
\hline$P$ & 0,01 & 0,32335 \\
\hline
\end{tabular}

\section{DISCUŢII}

În studiul nostru, pacienții cu TCA examinați $(\mathrm{n}=133)$ au prezentat la nivelul cavității orale

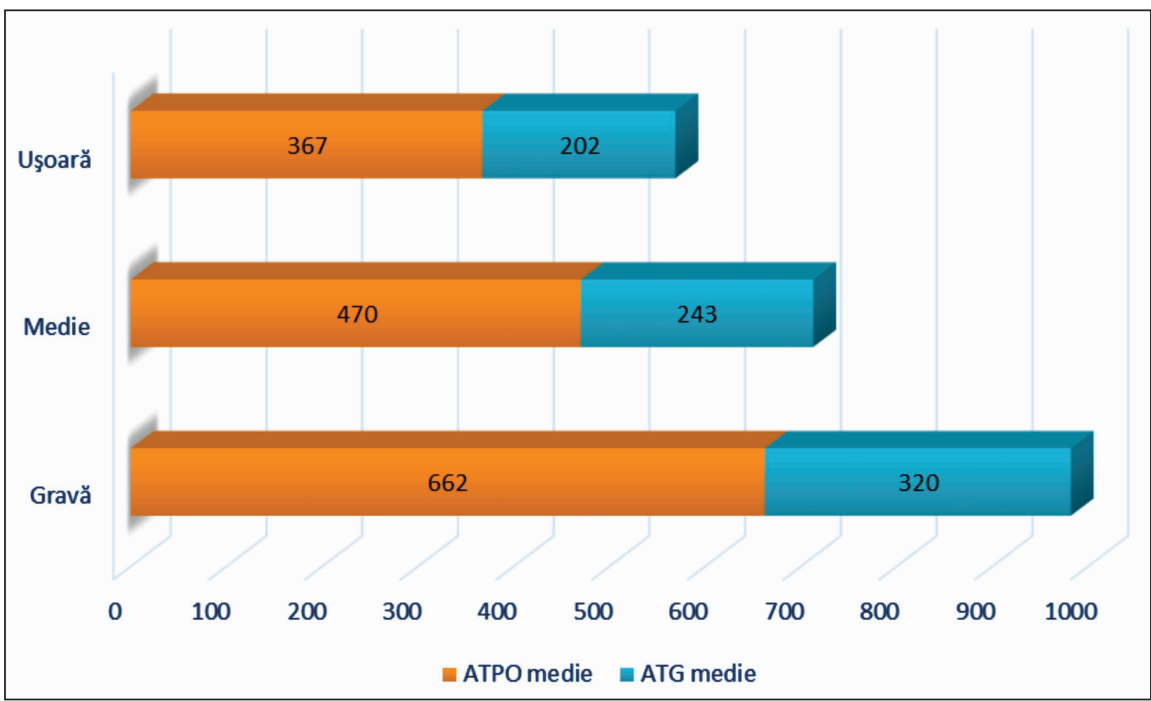

FIGURA 3. Profunzimea pungii parodontale, corelată cu nivelul mediu al Ac antitiroidieni 


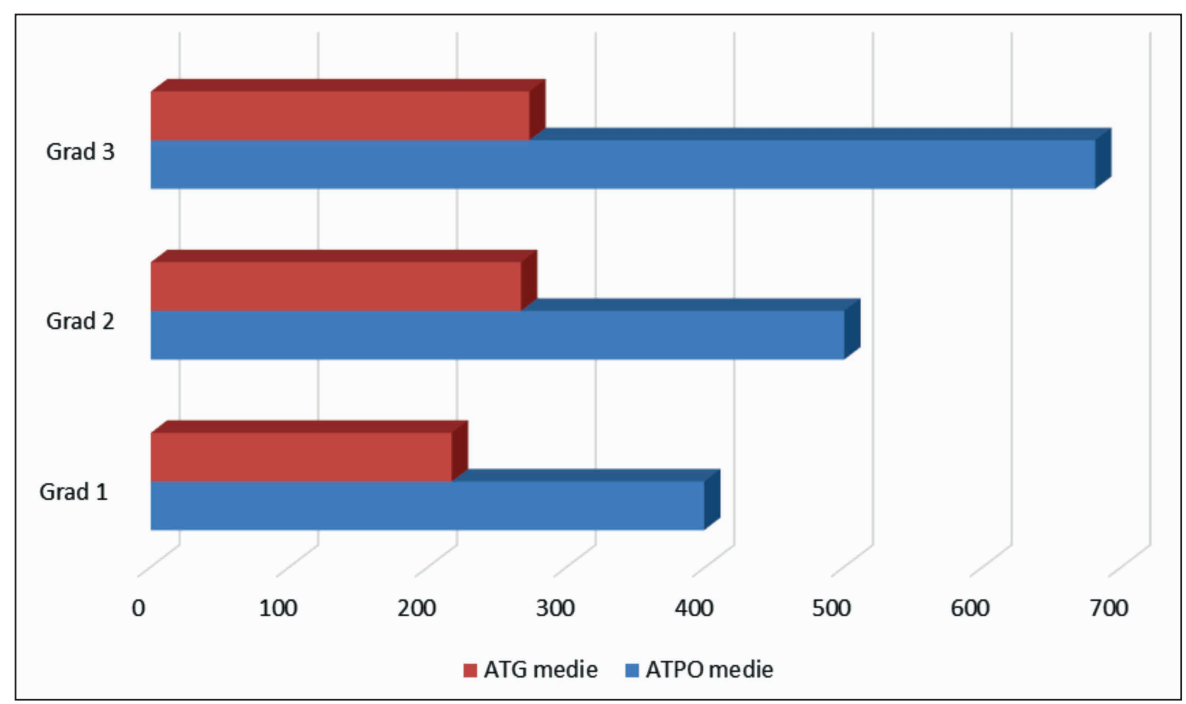

FIGURA 4. Gradul furcației radiculare corelat cu nivelul mediu al Ac antitiroidieni

$85 \%(n=109)$ leziuni de PC. Numărul redus al pacienților de sex masculin $(n=5 ; 4,5 \%)$ și, respectiv, sex feminin $(\mathrm{n}=104 ; 95,5 \%)$ nu a permis aprecieri specifice în funcție de variabilitatea de expresie a autoimunității între cele două categorii de pacienți, acest subiect nefiind propus în cazul studiului actual.

În rândul pacienților asociind $\mathrm{PC}, 62,3 \%(\mathrm{n}=$ 68) au prezentat ambele tipuri de anticorpi (ATPO și AcTg), iar 23,8\% au prezentat numai ATPO și 13,7\% AcTg. Studii similare menționează această distribuție specifică a autoimunității tiroidiene la pacienții cu TCA (10).

Nivelul seric mediu ATPO/AcTg apreciat după intensitatea leziunilor PC constatate - incipientă, medie, agravată - a constatat valori diferite în funcție de prezența numai a unui tip de anticorpi ATPO sau AcTg, sau prezența ambilor tipuri de anticorpi la aceiași pacienți (ATPO + AcTG). Valorile medii ale autoanticorpilor sunt în limite largi de variație și fără semnificație statistică privind clasele de anticorpi apreciate separat. Cumulul valorilor ATPO și AcTg de la întreaga categorie de pacienți, valori apreciate în funcție de intensitatea tipului lezional, a oferit însă rezultate diferite.

Diferenţe statistice s-au evidențiat între valorile medii ATPO comparate între grupul pacienţilor cu leziuni medii $(\mathrm{p}=0,00232)$, precum și între cei cu leziuni agravate şi leziuni incipiente $(\mathrm{p}=0,000003)$. $\mathrm{Nu}$ se remarcă o diferența statistică semnificativă între valorile AcTg și tipul leziunilor parodontale $(\mathrm{p}=0,06138)$.

Pacienții cu TCA fără afectare parodontală (placă bacteriană absentă) comparativ cu cei prezentând PC (placă bacteriană prezentă) nu au prezentat diferențe statistic semnificative între valorile medii ale concentrației serice ATPO $(p=0,10040)$, de asemenea între valorile medii ale concentraţiei $\operatorname{AcTg}(p=0,17681)$. Această constatare subliniază evoluția etapizată a BP supusă în faze inițiale efectului disbiozei cavitaţii orale $(6,7)$, la care se pot adauga și procese distructive de tip oxidativ prin componente salivare modificate (14).

Prezența sângerării gingivale ar putea fi corelată cu leziunile microcirculației capilare întâlnite în boli autoimune inclusiv TCA (17). În lotul de studiu, semnificația statistică a fost prezența în cadrul sângerării spontane gingivale comparativ cu sângerarea la sondare. Nu s-a remarcat o diferență semnificativă statistic între valorile AcTg și prezența sângerării gingivale $(p=0,13016)$.

Sub aspect lezional, prezența recesiei gingivale ar putea fi corelată evolutiv implicării mediatorilor inflamatori condiţionați de prezența autoanticorpilor și a specificului răspunsului tisular gingival $(3,4)$. În lotul studiat, valorile medii ale concentrației serice ale ATPO au fost semnificativ crescute $(p=0,00571)$ în cazul existenței recesiei gingivale comparativ cu absența acesteia. $\mathrm{Nu}$ s-au înregistrat diferențe statistice privind valorile $\operatorname{AcTg}(\mathrm{p}=0,41309)$.

Sub aspectul mobilităţii dentare, apreciată în funcție de gradul afectării parodonțiului, s-a constatat o diferență statistică între grupul pacienților cu mobilitate grad 3 față de cei grad 1 (p = $0,000123)$, precum și între cei cu grad 2 față de cei $\mathrm{cu} \operatorname{grad} 1(\mathrm{p}=0,000002)$. Nu s-a remarcat o diferența statistică între valorile AcTg și gradul mobilităţii dentare $(\mathrm{p}=0,15835)$.

Alterarea țesutului conectiv dentar în patologia tiroidiană este corelată prioritar funcției tiroidiene alterate (18). Prezența autoanticorpilor tiroidieni reprezintă un risc prioritar de evoluție spre hipotiroidie, precedată adesea de perioade cu funcție ti- 
roidiană echilibrată, alternând cu alterări ale nivelului de producție hormonală de intensitate subclinică, ce se pot însuma privind evoluția naturală a bolii autoimune tiroidiene (11).

Disbioza cavitații orale în bolile autoimune este o cauză principală a realizării pungilor parodontale (8), ca un răspuns local cu implicații autoimune sistemice (6). Nivelul seric al hormonului tireotrop hipofizar (TSH) destinat controlului funcției tiroidiene este implicat în modificări ale microbiomului salivar suferind fluctuații cantitative pe parcursul evoluției naturale a TCA (13). Valorile medii înregistrate ale ATPO în funcție de profunzimea pungii parodontale au înregistrat diferențe semnificative între cei cu leziuni grave față de cei cu leziuni ușoare, respectiv între cei cu leziuni medii față de cei cu leziuni ușoare $(p=0,00001)$.

În ceea ce privește furcația radiculară, nivelul seric mediu ATPO a fost semnificativ diferit între grupul pacienților cu furcație grad 3 față de cei de $\operatorname{grad} 1(\mathrm{p}=0,000011)$, precum și între cei de grad 2 față de cei de grad $1(p=0,007815)$. Nu s-a constatat o diferență semnificativă statistic privind valorile AcTg $(\mathrm{p}=0,25110)$. Prezența furcației radiculare, apreciată gradat, poate fi corelată existenței procesului distructiv $\mathrm{cu}$ interesarea țesutului conectiv de tip colagen I (2) și osos (9). Aceste procese distructive sunt rezultanta particularității de expresie a componentelor inflamatorii și imune ale PC influențate de variabilitatea genică a expresiei interleukinelor (7), prezența hipotiroidismului $(11,18)$, alte boli cronice $(15)$, vârstă ca durata de evoluție a bolii (4). Toate aceste constatări privind implicări ca mecanisme patogene cu acțiune individuală și mai frecvent cumulată sunt caracteristici potențial evolutive ale bolii autoimune tiroidiene (1).

Valoarea medie a concentrației serice ATPO în funcție de existența modificărilor ocluziei dentare a fost semnificativă $(p=0,001)$ comparativ cu un prag de 0,05 , dar fără semnificație statistică pentru valorile $\operatorname{AcTg}(p=0,32335)$.
Incongruența dentară caracterizează o alterare majoră a parametrilor ocluziei dentare, afectând parțial sau total funcția masticatorie. Cumulul factorilor lezionali distructivi de natură inflamatorie și imună acţionând prin activări de citokine, interleukine, limfocite $\mathrm{T}$ și $\mathrm{B}$, efecte oxidative celulare cu alterarea clearance-ului celular tisular, activări de enzime de degradare tip metaloproteinaze matriceale, resorbție osoasă intensificată prin semnalizare intercelulară alterată, precum și implicări directe ale hormonilor tiroidieni în metabolismul tisular al componentelor cavitații orale sunt constatări clinico-experimentale întâlnite atât în TCA, cât și în PC (18).

\section{CONCLUZII}

Parodontita cronică este prezentă într-un procent semnificativ dintre cazuri la pacienții cu tiroidită cronică autoimună, leziunile constatate putând fi incipiente (gingivită) până la agravate (incongruență dentară).

Patogenia parodontitei cronice este definită de procese autoimune amorsând mecanisme inflamatorii având drept cauză un cumul de factori, printre care și bolile tiroidei.

Deși rezultatele obținute privind intercorelarea mecanismelor de producere a leziunilor parodontale întâlnite la pacienții cu tiroidită cronică autoimună sunt dificil de sistematizat, intricarea autoimunităţii de organ (tiroidită) cu cea pluritisulară (parodontită) este sugerată de incidența crescută a asocierii celor două boli.

Nivelul seric mediu al anticorpilor ATPO semnificativ crescut în cazul leziunilor parodontale, proporțional și cu intensitatea lor, ia în discuție efectul sistemic indirect al acestora, cu complicații extratiroidiene, inclusiv parodontită cronică.

Se impune o abordare multidisciplinară, cu studii extinse la nivel populațional.

Conflict of interest: none declared Financial support: none declared

\section{BIBLIOGRAFIE}

1. Pan $W$, Wang $Q$, Chen $Q$. The cytokine network involved in the host immune response to periodontitis. Int J Oral Sci. 2019 Nov 5;11(3):30.

2. Du M, Wang Y, Liu Z, Wang L, Cao Z, Zhang C, Hao Y, He H. Effects of IL-1 $\beta$ on MMP-9 Expression in Cementoblast-Derived Cell Line and MMP-Mediated Degradation of Type I Collagen. Inflammation. 2019 Apr;42(2):413-425.

3. Yucel-Lindberg T, Båge T. Inflammatory mediators in the pathogenesis of periodontitis. Expert Rev Mol Med. 2013 Aug 5;15:e7.

4. Ebersole JL, Graves CL, Gonzalez OA, Dawson D 3rd, Morford LA, Huja PE, Hartsfield JK Jr, Huja SS, Pandruvada S, Wallet SM. Aging, inflammation, immunity and periodontal disease. Periodontol 2000. 2016 Oct; $72(1): 54-75$.

5. Marson A, Housley WJ, Hafler DA. Genetic basis of autoimmunity. J Clin Invest. 2015 Jun;125(6):2234-41.

6. Suárez LJ, Garzón H, Arboleda S, Rodríguez A. Oral Dysbiosis and Autoimmunity: From Local Periodontal Responses to an Imbalanced Systemic Immunity. A Review. Front Immunol. 2020 Dec 8;11:591255. 
7. Borilova Linhartova P, Danek Z, Deissova T, Hromcik F, Lipovy B, et al. Interleukin Gene Variability and Periodontal Bacteria in Patients with Generalized Aggressive Form of Periodontitis. Int J Mol Sci. 2020 Jul 2;21(13):4728.

8. Mathis $\mathrm{D}$, Benoist $\mathrm{C}$. Microbiota and autoimmune disease: the hosted self. Cell Host Microbe. 2011 Oct 20;10(4):297-301.

9. Hienz SA, Paliwal S, Ivanovski S. Mechanisms of Bone Resorption in Periodontitis. J Immunol Res. 2015;2015:615486.

10. Patil BS, Patil S, Gururaj TR. Probable autoimmune causal relationship between periodontitis and Hashimotos thyroidits: a systemic review. Niger J Clin Pract. 2011 Jul-Sep;14(3):253-61.

11. Aldulaijan HA, Cohen RE, Stellrecht EM, Levine MJ, Yerke LM. Relationship between hypothyroidism and periodontitis: A scoping review. Clin Exp Dent Res. 2020 Feb;6(1):147-157.

12. Lertpimonchai A, Rattanasiri S, Arj-Ong Vallibhakara S, Attia J, Thakkinstian A. The association between oral hygiene and periodontitis: a systematic review and meta-analysis. Int Dent J. 2017 Dec;67(6):332-343.

13. Dong T, Zhao F, Yuan K, Zhu X, Wang N, Xia F, Lu Y, Huang Z. Association Between Serum Thyroid-Stimulating Hormone Levels and Salivary Microbiome Shifts. Front Cell Infect Microbiol. 2021 Feb 26;11:603291.
14. Morawska K, Maciejczyk M, Popławski Ł, Popławska-Kita A, Kretowski A, Zalewska A. Enhanced Salivary and General Oxidative Stress in Hashimoto's Thyroiditis Women in Euthyreosis. J Clin Med. 2020 Jul 3;9(7):2102.

15. Cardoso EM, Reis C, Manzanares-Céspedes MC. Chronic periodontitis, inflammatory cytokines, and interrelationship with other chronic diseases. Postgrad Med. 2018 Jan;130(1):98-104.

16. Tonetti MS, Greenwell H, Kornman KS. Staging and grading of periodontitis: Framework and proposal of a new classification and case definition. J Periodontol. 2018 Jun;89 Suppl 1:S159-S172.

17. Kim JY, Park YB, Lee SW. Thyroid Dysfunction in Patients with Antineutrophil Cytoplasmic Antibody-associated Vasculitis: A Monocentric Retrospective Study. J Rheumatol. 2019 Sep;46(9):1248-1250.

18. Shcherba V, Kyryliv M, Bekus I, Krynytska I, Marushchak M, Korda M. A Comparative Study of Connective Tissue Metabolism Indices in Experimental Comorbidity-Free Periodontitis and Periodontitis Combined with Thyroid Dysfunction. J Med Life. 2020 AprJun;13(2):219-224. 